\title{
Obranné strategie obyvatelstva českého a ukrajinského původu na Ukrajině vyvolané následky černobylské nukleární havárie
}

\author{
Veronika Beranská - Zdeněk Uherek
}

DOI: $10.21104 / C L .2016 .1 .06$

The Defensive Strategies of Czech and Ukrainian Residents in the Ukraine against the Effects of the Chernobyl Nuclear Accident

\begin{abstract}
The text focuses on the theme of health care and amateur treatment in the extreme conditions of increased radiation after the explosion of the nuclear reactor at the Chernobyl power plant. It reconstructs the plight of the population from the accounts of residents living near the Chernobyl power plant, some of whom resettled in the Czech Republic, and analyses the relationship of the new state of affairs for folk healing. The text shows the logic of the adaptation mechanisms of the group of people to the new circumstances and their mobilization of the cognitive potential in the conditions in which professional aid and biomedicine, which they commonly used, failed. Besides the traditional practices of folk treatment, innovations based on scraps of information gathered from the mass media, reading, knowledge of a healthy lifestyle, the application of extreme medical cures devised by doctors through experimentation, assert themselves under extreme conditions. Other than the information on the application of specific methods and procedures, the text shows the process of how 'human wisdom' on health and disease is formed and adapts to a new, in this case extreme, situation. In an individualized, complex society, these ideas are distinctly private, flexible and situational.
\end{abstract}

Keywords medical anthropology, Ukraine, Chernobyl region, folk healing.

Text vznikl s podporou na dlouhodobý koncepční rozvoj výzkumné organizace RVO:68378076.

Contact Mgr. Veronika Beranská, Etnologický ústav AV ČR, v. v. i., Na Florenci 3/1420, Praha 1, 110 00, Czech Republic; e-mail: veronika.beranska@seznam.cz.

Doc. PhDr. Zdeněk Uherek, CSc., Etnologický ústav AV ČR, v. v. i., Na Florenci 3/1420, Praha 1, 110 00, Czech Republic; e-mail: uherek@eu.cas.cz.

Jak citovat / How to cite Beranská, Veronika - Uherek, Zdeněk. (2016). Obranné strategie obyvatelstva českého a ukrajinského původu na Ukrajině vyvolané následky černobylské nukleární havárie. Český lid 103, 103-118. doi:http:// dx.doi.org/10.21104/CL.2016.1.06 


\section{Úvod}

K problematice zdravotních následků černobylské jaderné exploze, jedné z největších ekologických katastrof způsobených člověkem, existuje již v současné době rozsáhlá literatura. Je též dobře známo, že stejně devastujícím způsobem, jakým následky černobylské katastrofy dopadaly na lidský fyzický organismus, působily neobyčejně zátěžově také na lidskou psychiku. Diana Scottová ve svém textu Healing in the Shadow of Chernobyl např́klad cituje Tetera Holbrooka, který v zasažených oblastech na běloruském kontaminovaném území vykonával sociální práci. Scottová hovoří především o pocitech beznaděje, psychické otupělosti a bezperspektivnosti, které doprovází strach způsobující poruchy spánku, ztrátu koncentrace a zájmu o cokoli, dále se zmiňuje o alkoholismu a dalších negativních jevech (Scott 1996). Jak jsme později zjištovali, tento stav byl nejen důsledkem vážné situace, ale také špatné informovanosti - resp. dezinformovanosti - obyvatel okolí černobylské elektrárny, kteří byli dlouho udržováni v nevědomosti a s nimiž si odpovědné úřady nevěděly rady. Do této atmosféry vstupoval problém imobility. V podmínkách Sovětského svazu nebylo snadné se z prostoru vystěhovat. Všechny tyto okolnosti motivovaly alespoň ty aktivnější obyvatele oblasti k pokusům zareagovat na situaci a chránit sebe a své rodinné příslušníky do takové míry, aby zdravotní rizika co nejvíce eliminovali.

Předložený text si klade základní otázku, jak obyvatelé na zdravotní rizika reagovali a jakým způsobem se je snažili vlastními prostředky eliminovat. Ptáme se, jaký znalostní potenciál obyvatelé oblasti aktivizovali a jakou souvislost měly jejich praktiky s „lidovou medicínou“. Svoje poznatky stavíme na dlouhodobém terénním výzkumu - založeném především na kvalitativních metodách rozhovoru a pozorování - mezi přesídlenci českého a ukrajinského původu z oblastí zasažených černobylskou jadernou katastrofou, kteří přišli do České republiky v letech 1991-1993 a s nimiž probíhala intenzivní interakce v letech 1991-1997. Sběry dat se uskutečňovaly nejprve v rámci šířeji koncipovaných projektů, v letech 1991-1993 v rámci projektu Grantové agentury České republiky s názvem Vliv objektivních a subjektivních faktorů na proměny etnicity u českého etnika v zahraničí (hlavní řešitel Stanislav Brouček) a následně v letech 19941997 v rámci projektu - rovněž podpořeného GA ČR - s názvem Procesy adaptace a společenské integrace přesídlenců z Ukrajiny, Běloruska a Kazachstánu $v$ České republice (hlavní řešitelka Nad'a Valášková). Na uvedené výzkumy navazoval terénní výzkum na Ukrajině v letech 2000-2002 a 2010. Poslední rozsáhlý sběr dat byl realizován $v$ rámci projektu podpořeného Grantovou agenturou Akademie věd České republiky s názvem Identita a sociabilita migrantů z bývalého Sovětského svazu: následný výzkum ř́zených migrací s důrazem na druhou generaci, který probíhal v letech 2008-2011 (hlavní řešitel Zdeněk Uherek).

Jednotlivé projekty byly zaměřeny na různé aspekty života zkoumaných skupin a vedle pozorování a rozhovorů se v jejich rámci uskutečnila též 
dotazníková šetření. Vzhledem k tomu, že šetření se především soustředila na českou menšinu na Ukrajině, která v kontaminovaných oblastech částečně dodnes žije, lze naše poznatky vztahovat především k tomuto menšinovému segmentu obyvatelstva, ne tedy k ukrajinskému obyvatelstvu v kontaminované oblasti obecně.

V tomto textu využíváme nikoli výsledky kvantitativních sběrů, ale výsledky kvalitativních rozhovorů, vzpomínek aktérů a též pozorování jejich příbytků a zahrad, odpovědí na otázky po pěstování a využívání bylin v České republice a zohledňujeme další kvalitativní data, a to z celého období, po něž byla data sbírána, to znamená od roku 1991 až po rok 2015. Nejčastější metodou sběru dat byl spontánní nestrukturovaný rozhovor, který se uskutečnil mezi autory studie a jejich partnery v rozhovoru.

\section{Terminologie}

Užití pojmu tradiční je ve vztahu k lidové léčbě poměrně komplikované, nebot' toto pojmenování není v lingvistické rovině jednoznačné. $V$ českém prostředí pojem tradiční referuje ke stabilitě, stálosti a neměnnosti, v anglosaském pojetí k původnosti a jedinečnosti vztahující se k místu a jednotlivým etnikům či kulturám. Podle World Health Organization (WHO) je „tradiční medicína souhrnem znalostí, dovedností a praktik založených na myšlenkovém systému, víře a zkušenostech původních (indigenous) a odlišných kultur a užívaných k udržení zdraví, stejně jako k prevenci, diagnóze, zlepšení nebo léčení fyzických či mentálních onemocnění“ (WHO 2014). Pro tu část léčebných praktik, které nejsou součástí místní tradice a nejsou integrovány do dominantního systému místní lékařské péče, používá WHO označení komplementární/alternativní medicína (zkráceně CAM). Termín lidová medicína (folk medicine) se v běžném anglosaském kontextu používá pro obojí, jak pro tradiční, tak pro alternativní medicínu a její další označení jako holistická (holistic) či východní (eastern). Všechna tato pojmenování se používají k odlišení od vládnoucího diskurzu západní biomedicíny (western, scientific medicine, biomedicine), která se označuje též jako alopatická (allopathic) (Folk Medicine and Traditional Healing 2011). Obecně platí, že v industriálních společnostech je užívání komplementární medicíny spojováno s vyšší př́ijmovou skupinou a vyšším vzděláním osob (Eisenberg - Davis Ettner 1998; Ong - Bodeker 2002), zatímco pro etnické minority v týchž společnostech je tradiční léčba mnohdy jedinou volbou v důsledku chudoby a nedostatečné jazykové kompetentnosti, kdy se jim konvenční léčba stává nedostupnou. Tradiční a komplementární léčba je však obecně na vzestupu - takřka polovina populace mnoha industrializovaných zemí v současné době pravidelně využívá nějakou formu tradiční nebo komplementární medicíny (např. Spojené státy $42 \%$, Austrálie $48 \%$, Francie $49 \%$, Kanada $70 \%$ ) a značný počet je zaznamenán též v méně rozvinutých zemích: Čína $40 \%$, Chile $71 \%$, Kolumbie $40 \%$, africké země až 80 \% (Bodeker - Kronenberg 2002). 
V textu proto v souladu s doporučením WHO pracujeme s pojmem lidová léčba, pod který zahrnujeme i léčbu tradiční, tak jak je běžné pro anglosaský kontext. K odlišení novátorských postupů v rámci obranných praktik proti radiaci používáme termín amatérská léčba, amatérské postupy.

Text je strukturován do několika navzájem provázaných úseků. V souvislosti s terminologickým ukotvením navazuje po uvedení do tématu představení několika příkladů lidového léčení u Čechů na Ukrajině, které ilustrují stav a výchozí podmínky pro vznik obranných strategií po havárii jaderné elektrárny. Popis amatérských postupů českých obyvatel ve stavu radiačního ohrožení je zde představen v provázanosti se zahraničními poznatky.

\section{Kontext}

Vliv kontextu na jednání lidí a tedy i význam studia kontextu při etnografické práci je dlouhodobě známou skutečností (Shokeid 1992). Obzvláště v současnosti si uvědomujeme, že kontext mění význam věcí a mění vztah věcí k uživateli do té míry, že se předměty mohou stát jeho součástí (Strathern 2004). V první řadě byla situace na Ukrajině pro místního občana velmi nepřehledná. Především panovala naprostá neinformovanost, nejistota a zmatek. Po 26. dubnu 1986, kdy došlo k nehodě ve čtvrtém bloku černobylské jaderné elektrárny na Ukrajině, se svět dozvídal o šíři katastrofy postupně a jen do určité míry. Tehdejší sovětský komunistický režim skrýval informace o nehodě nejen před vlastními obyvateli, ale i před sousedními státy. Teprve po roce 1989 nastala veřejná diskuse o plných důsledcích jaderné havárie. Svět byl tedy dlouhou dobu udržován bez relevantních dat, a to převážně z důvodu nedostatku volného toku informací a vzhledem k omezování volného pohybu osob.

První oficiální zpráva vyšla v Kyjevském večerníku až tři dny po katastrofě. Brzy poté evakuovaly sovětské úřady město Pripjat', kde se nacházela jaderná elektrárna, a okolní třicetikilometrovou zónu (Kužel 1997). Lidé ve vzdálenějších oblastech museli zůstat ve svých domovech, bez dostatečných informací o možnostech ochrany a prevence v situaci zvýšené radiace a bez jakékoliv pomoci (Abbott - Wallace - Beck 2006).

Podle neoficiálních zdrojů a podle shromážděných vzpomínek našich respondentů pouhá hrstka lidí obdržela informace o výbuchu bezprostředně v onen kritický den, někteří až druhý nebo třetí den po explozi. 0 tom, že se něco přihodilo, se dozvídali především jen v útržkovitých informacích od příbuzných, sousedů a kolegů, a to následujícím způsobem:

„Stavební dělník pracoval na budově asi 40 km vzdálené od epicentra výbuchu. Zahlédl záblesk a dým a odvodil z toho, že v Černobylu došlo $k$ neštěstí.“ (žena, rok narození 1929, Malá Zubivščina, Ukrajina)" „Zdravotní sestra pracovala v okresním městě Korosteň a v den výbuchu byla veškerá nákladní

Interview 21. 6. 1992 v Kuřivodech, okres Česká Lípa, Severočeský kraj. 
auta a autobusy vyslány do Černobylu. Nemocnice se připravovala na př́jem pacientů a z toho si místní obyvatelé vyvodili, že se stalo neštěstí.“ (žena, rok narození 1938, Malá Zubivščina, Ukrajina)²

Podobná vyprávění jsou zachycena také v literatuře, jako vyprávění starší ženy, která seděla venku na lavičce a užívala si slunného dne, když vtom: „náhle zastavilo obrovské obrněné auto přímo před námi. Muži s plynovými maskami a nějakými ochrannými obleky vyskočili a začali kolem nás chodit a odečítat ze zařízení na hrudi. Jeden se na nás podíval a připevnil na zem takovou malou věc s cizím symbolem, který jsme nikdy předtím neviděli. Pak naskočili zpátky do transportéru a odjeli. To vše se odehrálo v naprostém tichu. Nepadlo jediné slovo“" (Scott 1996).

Jestliže lidé tuší neznámé nebezpečí, je jejich první reakcí zájem získat co nejvíce informací o tom, co jim hrozí. Každý člověk, který cokoli viděl nebo slyšel o neštěstí, jež se událo, byl v tu chvíli velmi cenný. Naši aktéři tehdy žili ve vesnicích Malá Zubivščina a Malinovka a ve městech Korosteň a Malin, vzdálených přibližně 60-80 kilometrů od jaderné elektrárny, a nemohli proto spolehlivě slyšet nebo vidět, co se stalo. $V$ jejich lokalitách se přesto bezprostředně po výbuchu objevily informace, že někdo slyšel detonaci, viděl kouř a podobně. Postupně se $\mathrm{z}$ novinek skládal obraz, že část elektrárny vybouchla a že atmosféra je zamořená radiací:
„My jsme se to dozvěděli za šest dní.. Pak nám řekli, zavřete všechna okna, studně, všechno. No a my jsme o tom nic nevěděli. My jsme tomu nerozuměli, a pak jsme se dozvěděli, řekli nám, že tam zemřeli už tři hasiči, jiný ř́kali, že tam nikdo nezemřel, a potom, když jsem ležela $v$ nemocnici a dělali mi operaci, tak tam jeden z těch hasičů ležel a řikal: ,Nevim, jestli tu budu ležet ještě tejden nebo rok, ale už mám třikrát úplně vyměněnou krev. Kolikrát ji ještě můžou měnit, nevim: “(žena, rok narození 1924, Malinovka, Ukrajina) ${ }^{3}$

Lidé byli oficiálně vyzváni, aby se bez vážných důvodů nezdržovali venku a aby nejedli ovoce a zeleninu, které by nebyly umyty nezávadnou vodou, jež začala být dovážena ze vzdálených, nezasažených oblastí. Bylo jim doporučeno, že by měli omezit pití domácího mléka, a kde mléko již mělo být konzumováno, aby se nechalo odstát nebo se převařilo a odstranil se a vyhodil vrchní škraloup. Bylo jim též ukládáno, aby nejedli lesní ovoce a cokoli, co roste na zemi, a měli nařízeno mít zavřené studny, držet děti doma a chránit se proti prachu. Nikdo je však neinformoval, jak vážné toto nebezpečí opravdu je. Lidé tedy pátrali po znameních, která by jim o neštěstí v okolí pověděla více a prostř̌ednictvím přírodních úkazů. Znova a znova rekapitulovali neobvyklé jevy, které 
zaznamenali v den exploze. Vzpomínali si na neobvykle velké horko, které ten den bylo, a že obyvatelé měst i vesnic byli ten den všichni venku:

„A jeden taky vypravoval, taky inženýr, pracoval tam, a povídal: ,Dítě jsme měli maličké, asi tři měsíce, a byl velkej hic, tak jsme ho dali na balkón, a to dítě bylo za chvíli černé, jako nějakej prach:“(žena, rok narození 1936, Malinovka, Ukrajina) ${ }^{4}$

„Děti tam v blízkosti Černobylu seděly ve školách, a hrozně, krev jim šla z uší a z nosu, tam, černobylskejm. “(muž, rok narození 1931, Malá Zubivščina, Ukrajina) ${ }^{5}$

„A lidi to cejtili, protože to strašně škrábalo a pálilo v krku, v očích to pálilo a lidi byli unavený pořád.“ (muž, rok narození 1967, Korosteň, Ukrajina) ${ }^{6}$

Též bylo zaznamenáno vyprávění, že v následujících dnech se v lesích objevilo velké množství hub a že dorůstaly neobvykle velkých rozměrů - velké houby byly často zmiňovány jako přímý indikátor výskytu radiace. Také vyprávěli, že pravděpodobně vzhledem k radiaci byla zelenina v roce 1986 neobvykle velká a stejně tak i ovoce.

„... a listí padalo černé ze stromu ... v létě, bylo jako spálené.“ (žena, rok narození 1916, Malá Zubivščina, Ukrajina) ${ }^{7}$

Ve zmíněných městech a vesnicích však žili kvalifikovaní specialisté. Mezi obyvateli byli též lékaři, záchranáři, vojáci, kteří byli lépe informováni o důsledcích zvýšené radiace. I oni své dílčí znalosti šírili mezi svými sousedy a byly zde již zmíněné místní orgány se svými nařízeními a doporučeními. Lidé v zasažených lokalitách kombinovali tyto útržky informací se svojí vlastní zkušeností a se znalostmi svých příbuzných, jak si pomoci při nejrůznějších zdravotních potížích.

Teprve po několika letech se lidé dozvídali, jakého rozsahu bylo radio-aktivní zasažení, které prostřednictvím radioaktivního spadu kontaminovalo severní Ukrajinu včetně Kyjeva, západní části Ruska a jižní a východní Bělorusko. $\mathrm{V}$ uvedených oblastech úroveň radioaktivity mnohonásobně převýšila běžné hodnoty a k vyrovnání tohoto stavu na běžnou úroveň bude třeba 300 let i déle (Metivier 2002). Ve výpovědích našich aktérů proto mnohokrát zazněla kritika odpovědných orgánů, které místní obyvatelstvo nedostatečně informovaly: 
„Ještě na prvního května byly všude průvody, všichni, školy, děti venku a nikdo nic neřek. "8

„Jak hasili reaktor, tak z něj šla pěna, jak ten reaktor hořel, a děti, tak ty děti si $v$ tom normálně hrály, šplíchaly se v tom.“ (muž, rok narození 1931, Malá Zubivščina, Ukrajina) ${ }^{9}$

\section{Aktéři}

Jak jsme již uvedli, většina našich informátorů žila v době katastrofy ve vzdálenosti 60-80 kilometrů od černobylské elektrárny. V 90. letech 20. století se většina z nich přestěhovala do České republiky, a to ze tří nejfrekventovaněji uváděných důvodů:

1. ekonomických (práce),

2. sociálních (sloučení rodin na území ČR, následování životního partnera, životní perspektiva),

3. zdravotních.

Nejpočetnější skupiny, u nichž převažovaly zdravotní důvody, přicestovaly z Ukrajiny do České republiky na počátku 90. let v počtu přibližně 2000 osob a byly usídleny v lokalitách po celé republice. Britská socioložka Claire Wallaceová je například nazývala ekologickou migrací (Wallace - Stola 2001). Ministerstvo vnitra, které migraci osob z postižených oblastí jako humanitární pomoc zabezpečovalo, poskytlo skupině možnost se přestěhovat do renovovaných bytů a pomohlo alespoň jednomu z rodinných příslušníků nalézt zaměstnání, které však zpravidla neodpovídalo jeho kvalifikaci (Valášková Uherek - Brouček 1997; Uherek 2009; Uherek - Beranská 2015).

Aktéři navštívení na Ukrajině byli převážně příbuzní těch, s nimiž jsme byli v kontaktu v České republice. Pokud byli v kontaminovaných oblastech, zůstali tam zpravidla z rodinných důvodů, anebo protože nemohli následovat své příbuzné v letech 1991-1993, kdy probíhaly řízené migrace do České republiky a kdy bylo přesídlencům poskytováno ubytování a zabezpečováno zaměstnání. $v$ pozdějších letech, kdy již asistence státu skončila, bylo přesídlení z kontaminované oblasti už obtížně realizovatelné. ${ }^{10}$

8 Téměř všichni, kdo hovořili o jaderné katastrofě, použili tuto formulaci.

9 Interview 14. 7. 1992 v Butovsi, okres Jičín, Východočeský kraj.

10 Domy na Ukrajině v kontaminované oblasti se obtížně prodávaly a úspory aktérů zpravidla nedostačovaly k zabezpečení důstojného života v České republice. Navíc ukrajinská vláda poskytovala zvláštní př́iplatky, aby obyvatelstvo v kontaminované zóně stabilizovala. Příplatky zvyšovaly životní úroveň obyvatel v postižených oblastech a snižovaly motivaci k odchodu. Lidé jim zde říkali „pohřebné“. 


\section{Předpoklady pro formování léčebných obranných strategií}

Přestože velká část našich aktérů pocházela z venkovského prostředí, většina měla nezemědělská povolání a byli mezi nimi středoškoláci i univerzitně vzdělaní lidé. Na jejich myšlení měl vliv život v socialistickém státě. Od roku 1917 naši respondenti a jejich předkové žili v sovětském socialistickém prostředí a byla jim poskytována institucionalizovaná zdravotní péče s nulovou tolerancí alternativních léčebných metod. Lidové léčení bylo zakázáno stejně jako provázanost zdravotní péče s pohanstvím. Je třeba též zmínit, že samotné označení ukrajinská medicína je poněkud problematické, nebot podobně jako jiné medicínské komplexy je složená z mnoha výpůjček a složenin prolínajících se vlivů, v tomto případě navíc potlačených a od 30. let 20. století násilně rusifikovaných a vtěsnaných do celku sovětské medicíny (Hanitkevych 2005). Nicméně místní znalost fytoterapie přežila celou komunistickou éru a my jsme zaznamenali několik oblastí lidského zdraví, ve kterých se lidová léčba uplatnila. ${ }^{11}$

Léčba přesídlených Čechů z Ukrajiny je charakteristická zejména svou synkretičností, která spočívá v prolínání původních znalostí z českých zemí druhé poloviny 19. století a nabývání nových postupů a vědomostí na Ukrajině. Podobná situace je vysledovatelná například u ukrajinských imigrantů, kteří se usadili v Kanadě (okolí Alberty, Manitoba atd.) a po celé 19. století využívali převážně na odlehlých zemědělských usedlostech domácí léčiva a po generace předávané léčivé receptury (Mucz 2012; Klymasz 1989). Také oni byli ovlivněni širokým spektrem vědomostí získaných ve zdrojových zemích a postupně se proměňujících a přizpůsobujících se novým podmínkám v novém prostředí. I v jejich praktikách jsou vysledovatelné postupy a recepty příbuzné těm obsaženým ve vyprávěních českých přesídlenců z Ukrajiny.

Lidová léčba Čechů na Ukrajině byla používána především na lehčí formy těch onemocnění, která nevyžadovala zásah lékaře, jako bylo nachlazení, virová infekce, popáleniny a jiná poranění kůže, únava, bolesti hlavy, žaludku atd. Respondenti hovořili například o použití měsíčku lékařského (Calendula officinalis) na otoky nohou - „tu calendulu na zahrádce si sbírám ... a pak ten spiritus dělám a potírám si ty nohy bolavý“ (žena, rok narození 1939, Malá Zubivščina, Ukrajina), ${ }^{12}$ kopřivy dvoudomé (Urtica dioica) na problémy urogenitálního traktu - „ty tuhle u okna sušim, mám je na ledviny ... támhle za barák na ně chodim... “ (žena, rok narození 1940, Malinovka, Ukrajina), ${ }^{13}$ směsi pepře, medu a alkoholu na nachlazení: 
„Já znám taky takový recept, to jste mi připomněla ... vezme se 1 dcl vodky a lžička pepře mletého ... pak se napustí vana plná horké vody a to vám vyleze ten začátek chřipky póry, jak se člověk zapotí, pak se zaleze do postele a vypotí se. Ráno je pak člověk úplně zdráv. Musí mít ale zdravý srdce... Na nachlazení pak ještě jeden znám ... vezme se šípkový sirup, lžička medu a koňak, ještě se může přidat citronová štáva, a to je na nachlazení a imunitu dobrý... “(muž, rok narození 1946, Malá Zubivščina, Ukrajina) ${ }^{14}$

Jako další příklad lidové léčby může posloužit bílá lilie (Lilium candidum) v lihu jako tzv. babské mazání na dezinfekci a bolesti zad, nebo žito (Secale cereale) na léčbu cukrovky: „Manžel si přivezl z Ukrajiny na cukrovku žito, někde to přečetl, že je to dobrý ... povaří se žito a pak tu tekutinu, vývar pít, někde to vyčetl a tak to zkusil..." (žena, rok narození 1951, Malá Zubivščina, Ukrajina), ${ }^{15}$ rakytník řešetlákový (Hippophae rhamnoides) na nachlazení, kašel nebo odřeniny atd. Důležitou roli na Ukrajině sehrávali též praktici, za kterými lidé přicházeli primárně s léčbou bradavic a neobvyklými bulkami pod kůží (Stickley - Koyanagi - Richardson - Roberts - Balabanova - McKee 2013).

Další oblast lidového léčení na Ukrajině, kterou jsme zaznamenali ve vzpomínkách českých přesídlenců, obsahuje prvky lidové sympatetické (homeopatické) magie se zvukomalebnými zaříkáváními. Tato oblast vykazuje archaické prvky lidového folkloru a je vysledovatelná v živé podobě na Ukrajině až do konce 20. století (Phillips 2004). V České republice je zadokumentovaná ještě jako živá praktika například v př́ípadě léčby mzí (úbytí) kolem poloviny 20. století (Polák 1943).

Jako další případ lze zmínit léčbu bolestivého streptokokového kožního onemocnění zvaného růže nebo také oheň sv. Antonína (lat. erysipelas), při kterém se používala směs sušených a rozmělněných plátků růže, květů heřmánku a lnu spolu se šeptáním modlitby nad doutnajícím plamenem:

„Vzala heřmánek, len a sesbírala okvětní lístky růží ... pak takhle rozbiji to stéblo lnu, rozmíchá to. Napálí dřiví, torf (víte co to je? ... no, to jak na dně řeky je, z torfu se rašelina dělala do čtverců a pak na pálení), tak dělala uhlí, posypala heřmánkem, plátky růží, nad tím ohřejvala a šeptala ... věřte, nevěřte, pomohla." (žena, rok narození 1940, Malá Zubivščina, Ukrajina, vzpomínka na vlastní babičku léčitelku jménem Anastasia Rybova, cca 1895-1959). ${ }^{16}$

14 Interview 8. 10. 2011 v Jaroměři-Josefově, okres Náchod, Královéhradecký kraj. 
Ritualizované formy léčení byly zaznamenány zvláště u onemocnění způsobených uřknutím, tzv. evil eye, nebo u výše zmíněného onemocnění zvaného mze, které se vyznačovalo únavou, malátností, zíváním a celkovou slabostí (více viz Beranská 2013; Kindl 2010). U těchto rituálních praktik nelze též určit míru synkreze, nebot tyto rituální praktiky a zaříkání se vyskytovaly nezávisle na sobě jak v českých zemích, tak na Ukrajině. Zajímavé je v tomto ohledu srovnání opět s ukrajinskými (a v mnohém i českými) imigranty, tentokráte však usídlenými v Kazachstánu. Odešli přibližně ve stejnou dobu jako ukrajinská migrační vlna směřující do Kanady, jejich folklor a kulturní praktiky, ač vykazují podobnost s ukrajinskými praktikami na Ukrajině, v Kanadě i v Čechách, se pochopitelně liší v přizpůsobení novému místu.

V Kanadě zachovali Ukrajinci léčebné postupy převzaté z Ukrajiny, avšak zbavily je přívlastku rituálních praktik a magického vidění světa, nebot' sociální konvence v Kanadě k tomu vybízela (Kononenko 2011). V Kazachstánu se naopak magické vidění světa zachovalo jak u českých imigrantů (Uherek et al. 2003), tak u ukrajinských imigrantů, kde bylo díky těžkým životním podmínkám navíc posíleno (Kononenko 2011).

Tyto výše zmíněné příklady ukazují poměrně velkou variabilitu a samostatnost českých obyvatel na Ukrajině ohledně samoléčebných praktik a poukazují na kreativitu a invenci v jejich myslích, která po havárii černobylské jaderné elektrárny vyústila v první pomoc proti ozáření a jeho následkům.

\section{Role lidové léčby a lidových praktik po černobylské jaderné havárii}

Ulrich Beck poznamenává, že Černobyl se stal pro západní Evropu „antropologickým šokem“. Šok pramenil především z faktu, že každodenní zkušenost lidí se tváří v tvář této katastrofě jevila jako nepoužitelná, a stejně tak se jevily i znalosti odborné (Beck 1987). Radiace byla všudypřítomná a představy o tom, kde je nebezpečí menší, se lišily od člověka k člověku. Někteří se domnívali, že největší nebezpečí je ve vzduchu, jiní zastávali názor, že všechno se spláchlo do půdy. Logickou a relativně dostupnou obrannou strategií bylo změnit stravovací návyky, ale vzhledem k odlišným názorům na největší zdroje nebezpečí přizpůsobovali lidé stravování této situaci diferencovaně a jednoznačně neakceptovali ani doporučení šířená státními orgány (Abbott - Wallace - Beck 2006). Do kontaminovaných oblastí se postupně začaly dovážet některé základní potraviny, zpravidla však byly drahé. Naopak levné místní potraviny, přestože byly kontaminované, se vyvážely i do dalších částí Sovětského svazu: „... ale stejně přijeli až z Dombasu, tisíc kilometrů ... tam, kde nebyly brambory, a vozili je tam od nás. “(muž, rok narození 1931, Malá Zubivščina) ${ }^{17}$ 
Mnozí lidé z kontaminovaných oblastí tak nakonec rezignovali na jakoukoli specifickou ochranu zdraví: „A pak nám radili, abysme např́klad nepili mlíko, ale jak, vždycky jsme ho pili, bylo to naše vlastní.“ (muž, rok narození 1924, Malin) ${ }^{18}$

Přijetí oficiální propagandy jak chránit své zdraví v určitém smyslu znamenalo přijmout nové životní podmínky v kontaminované zóně. Odmítnutí nových hygienických podmínek může být interpretováno také jako určitý typ protestu. Jak Anne Keaneová realisticky poznamenala: „Strava a moc jsou všude úzce propojeny ... nebot' ,zdravé stravování je prostě politická věc' na počernobylské Ukrajině stejně jako kdekoli jinde na světě.“ (Keane 1997: 179) A tak obyvatelé kontaminovaných oblastí kupovali levnější potraviny bez označení, že výrobek prošel radiační kontrolou a není kontaminován, a peníze utráceli za jiné zboží. Na otázku proč, odpovídali: „Mám zemřít hlady? Lepší zemřít na radiaci než hladem... “19 (Abbott - Wallace - Beck 2006: 115)

Velká část obyvatel adaptovala některé lidové léčebné metody situaci po vystavení radiačnímu záření. Za příklad poslouží užití brambor nebo syrových vajec na zvětšené lymfatické uzliny. Užití vajec bylo přítomno na Ukrajině již před nukleární havárií, vejce se využívala při těchto diagnózách a k léčbě zvláště v centrální části země, kde se stala analogií pro voskový rituál charakteristický pro západní části Ukrajiny (Phillips 2004). V České republice jsme zachytili vzpomínané užití vajec při léčbě zduřelých lymfatických žláz u respondenta z Malé Zubivščiny (muž, rok narození 1946, Malá Zubivščina, Ukrajina):

„A po Černobylu se jednomu synovci zvětšily žlázy takhle na krku ... a to jsem viděl, jak báby berou vejce, syrový, a kutálí po tom krku a šeptají modlitbu ... a pomohlo to, opravdu to pomohlo ... asi to vejce má něco, že tak vytáhne to...”20

Velký význam se přikládal také filtraci. Lidé byli poučeni, že radioaktivita je v mléku, ve vodě, v ovoci i zelenině. Radioaktivita je ale neviditelná a lidé nevěděli, jak ji odstraňovat. Měli však zkušenost, že znečištěné tekutiny mohou být filtrovány. Některé rodiny tak usoudily, že účinnou metodou by mohlo být filtrovat mléko přes pecen chleba. $V$ jiných rodinách se usuzovalo, že všechno, co roste nad zemí, je sice nebezpečné, ale plodiny, z nichž se jí to, co roste pod zemí, jsou méně škodlivé.

Další strategií byl proces filtrace trávicím traktem domácích zvířat. Podle této teorie vše, co jím projde, je více méně očištěno. Maso krávy by tedy mělo být méně zamořené než například voda, která přijímá radiaci z kontaminovaného

18 Interview 28. 11. 1993 ve Stráži pod Ralskem, okres Česká Lípa, Liberecký kraj.

19 Respondentka z Ukrajiny.

20 Interview 8. 10. 2011 v Jaroměři-Josefově, okres Náchod, Královéhradecký kraj. 
okolí. Poučky, jichž obyvatelé k ochraně svého zdraví využívali, však nebyly nijak sociálně kodifikované. Názory se v jednotlivých rodinách lišily. Některé rodiny považovaly například mléko $\mathrm{z}$ domácích zdrojů za relativně neškodné, a některé nikoli.

Někteří z místních obyvatel se snažili udržet zdraví nákupem levnějších potravin, které konceptualizovali jako radioprotektory, neboli jídlo s funkcí sorbentu, které mělo schopnost navázat radionuklidy v organismu a odvést je z těla ven (Phillips 2002: 9). Jako př́íklad látek s radioprotektivním charakterem poslouží vitamíny C, A a E, betakaroten, pektiny, jód a kyselina listová (z jídla např́íklad zeleninové saláty s mořskou řasou, jablka obsahující vlákninu pektin, mrkev a podobně zbarvená zelenina s obsahem karotenu) (Phillips 2002: 8). Úřady naopak doporučovaly nekonzumovat produkty z vlastních zahrádek a pozemků v kontaminované zóně, avšak místní ekonomika rodin byla založena především na levné domácí produkci.

Alternativní reakcí na kontaminované prostředí, která se nabízí, je nejíst vůbec nic. Někteří obyvatelé se vydali i touto cestou a vsadili na léčbu A. I. Vorobjeva, ruského akademika, při níž se podrobili dlouhému léčebnému hladovění, které mělo zajistit vyloučení radionuklidů z organismu. Jiní zase následovali Valerije Jerofejeva, který doporučoval v první etapě 21 denní hladovku a ve druhé etapě podání radioprotektivních prostředků, kdy ponejvíce doporučoval lněná semínka, výluhy a štávy z bylin, odvary z borůvek a dokonce i měd'. Stravu uváděl obdobnou, jaká je doporučována onkologickým pacientům. Svá doporučení spolu s jinými historickými pojednáními o lidové léčbě (popisuje například léčení žížalami či pijavicemi) shrnul v publikaci Unikátní metody lidových léčitelů (Jerofejev 2003).

Samozřejmě že existovaly velké skupiny lidí, které na jakoukoli prevenci rezignovaly. Dojem úpadku byl paradoxně prohlouben systémem finanční kompenzace pro obyvatele žijící v blízkosti jaderné elektrárny. Peněžní benefit, nazývaný místními lidmi jako „pohřebné“, umožňoval skromné živobytí na útraty státní pokladny, a lidé tak mohli rezignovat na jakoukoliv činnost. Tento ukrajinský kompenzační systém byl kritizován Ukrajinci a Bělorusy, kteří v něm spatřovali „boj o moc a materiální zdroje v souvislosti s katastrofou“ (Petryna 2004). Pohřebné nezvýšilo migraci z kontaminované zóny. Mnoho lidí se stalo závislými na finančních kompenzacích, které je stabilizovaly na místě. Dokonce byly zaznamenány případy, kdy se naopak lidé z mírně zasažených oblastí vystěhovali do kontaminovaných zón právě s výhledem na „pohřebné“.

\section{Závěr}

Černobylská jaderná havárie v roce 1986 je dramatickým př́́kladem typu událostí, které jsou charakteristické pro tzv. risk society, rizikovou společnost 
(Abbott - Wallace - Beck 2006). Podle autorů Abbottové, Wallaceové a Becka (2006) utrpení obyvatel bylo umocněno ekonomickým kolapsem, který následoval po rozpadu bývalého Sovětského svazu v roce 1991 a zanechával je v prostředí, které Rinkevicius (2000) nazval „double risk societies“, dvojitě rizikové společnosti. Černobyl byl spojován se zhroucením sovětského života obecně. Podle Adriany Petrynové se Ukrajina stala nejpřesvědčivějším místem ke zkoumání vztahů mezi rizikem, racionálně-technickou mocí a vznikem 3,5milionové nové populace nesoucí název „trpící“ (poterpili), kteří tvořili až $7 \%$ populace (politická ekonomie nemoci) (Petryna 2004).

Strategie, jakými se lidé vyrovnávali se zdravotními riziky, odkazují na společnost, v níž se léčení uskutečňovalo. Stát negeneroval kolektivně akceptovatelné strategie, a tak si každá rodina vytvářela své vlastní, které též sama „racionálně“ zdůvodňovala. Navazovala spíše na privátní poznatky, vědomosti, vzpomínky a další typy informací, které generovaly postupy někdy blízké i magickým praktikám. Podobný charakter měly též léčebné praktiky využívané proti radioaktivitě v uralské vesnici Muslumovo, které studovala Galina Komarovová (1997). V blízkosti černobylské jaderné elektrárny nebyly léčebné postupy podrobovány kolektivní kodifikaci v rámci vesnice, české menšiny nebo jakéhokoli širšího společenství. Zůstávaly v rovině osobních nebo rodinných experimentů, podobně jako další chování ve fragmentované, nekoherentní společnosti. Kolektivně akceptovanou a hojně uplatněnou strategií se nakonec stala pro mnohé aktéry až emigrace z kontaminovaného prostředí.

Jak ale ukázala nedávná tragická havárie další jaderné elektrárny v březnu roku 2011 v Japonsku, ne vždy musí mít na dopad událostí politické klima a rozpad stávajících struktur tak významný vliv. Po zemětřesení a následné tsunami v regionu Tóhoku, prefektuře Fukushima, jež byly příčinou roztavení přehřátého jádra nukleárního reaktoru ve Fukushima Daiichi nukleární jaderné elektrárně, následovala situace ne nepodobná okolnostem v ukrajinském Černobylu v roce 1986. A přestože se jedná o císařský ostrovní stát ve východní Asii, zcela jiné vládní uskupení, jiný politický aparát a odlišné ekonomické zázemí než panovalo v bývalém Sovětském bloku, následné události ukázaly řadu podobností. Asi většina obyvatel současného světa by očekávala spíš více kontrastů než paralel s jadernou havárií v Černobylu roku 1986, jak na to poukazuje i Sarah Phillipsová, jež vedla rozhovory s lidmi přeživšími jadernou havárii na Ukrajině i ve Fukušimě (více viz Phillips 2013). Lidé žili s hrozbou a v nejistotě. V literatuře se setkáváme s analogií života s chronickým onemocněním (Abbott - Wallace - Beck 2006; Bury 1982). I v okolí Fukušimy mezi lidmi panoval strach, nejistota a skepse ohledně jejich dalšího života a zdraví. Lidem s výrazným psychologickým a emočním stresem ve Fukušimě mohla být odborníky též připsána diagnóza tzv. radiofobie (Petryna 2002). Strach, posttraumatická stresová porucha a další psychické poruchy se staly charakteristickým rysem post-radiační situace rovněž ve Fukušimě (Brumfiel 2013). 
Jak je patrné z výše zmíněných příspěvků, lidé byli po černobylské katastrofě závislí především sami na sobě a svých znalostech, které museli využít a modifikovat, přizpůsobit nastalé urgentní situaci. Léčitelství, které převážně čerpalo z lidové tradice a bylo stacionárním souborem metod a praktik k navracení zdraví při běžných, život neohrožujících chorobách, se stalo vysloveně užitkovou činností se změněným životním modem a s prostředky přizpůsobenými odlišným podmínkám v situaci, kdy lidé neměli jinou možnost jak si pomoci. $\mathrm{Z}$ tradice se tak stala živá alternativa eklektického charakteru s ryze utilitárním zaměřením.

Proměnlivost lidové léčby je poměrně běžný rys, přestože její časté označení jako tradiční implikuje neměnnost. Dynamika proměn může být typologicky různorodá. Může se jednat o proměnlivost ve vztahu k místu působení léčby, např́íklad při přemístění osob, které ji vykonávají. Patrné je to například u již zmíněných ukrajinských imigrantů usazených v Kanadě, kde se léčebné praktiky přivezené $\mathrm{z}$ původní vlasti postupně adaptovaly na dostupnost místních lokálních zdrojů (Mucz 2012: 15). Zároveň však zůstává uchováno jádro těchto praktik, které tvoří základ lidové léčby (Mucz 2012; Klymasz 1989). V případě černobylského léčení se naopak jedná o proměnu danou změnou životních podmínek, které nastaly $\mathrm{v}$ původním prostředí aktérů, a motivací $\mathrm{k}$ dynamickým proměnám se stala změna životního prostředí a především strach o život, motivačně mnohem významnější podnět k inovativnímu chování.

V současné době žijí přesídlenci, o nichž byla řeč, mimo kontaminované území - v tomto prrípadě v České republice - již více než 20 let. Přesto však používají některé léčebné praktiky dodnes. A co více, našli bychom mezi nimi i osoby obchodující se zbožím, které může do jisté míry snížit následky a vliv radiace (více viz Uherek - Beranská 2015).

\section{Únor 2016}

\section{Literatura}

Abbott, Pamela - Wallace, Claire - Beck, Matthias. 2006. Chernobyl: Living with risk and uncertainty. Health, Risk \& Society 8, 2: 105-121.

Beck, Ulrich. 1987. The Anthropological shock: Chernobyl and the contours of a risk society. Berkeley Journal of Sociology 32: 153-165.

Beranská, Veronika. 2013. Krajanská lidová léčba a ritualizované praktiky u Čechů z Ukrajiny a Kazachstánu přesídlených do České republiky. Národopisná revue 23, 4: 264-271.
Bodeker, Gerard - Kronenberg, Fredi. 2002. A Public Health Agenda for Traditional, Complementary, and Alternative Medicine. American Journal of Public Health 92, 10: 1582-1591.

Brumfiel, Geoff. 2013. Fukushima: Fallout of Fear. Nature. International Weekly Journal of Science 493, 7432. [2015-11-28] Dostupné z: http://www.nature.com/ news/fukushima-fallout-of-fear-1.12194.

Bury, Michael. 1982. Chronic illness as a biographical disruption. Sociology of Health and Illness 4: 167-182. 
Eisenberg, David M. - Davis, Roger B. Ettner, Susan L. et al. 1998. Trends in alternative medicine use in the United States, 1990-1997: results of a follow-up national survey. JAMA 280: 1569-1575.

Folk Medicine and Traditional Healing. 2011. National Center for Farmworker Health. [2016-02-16] Dostupné z: http://www. ncfh.org/uploads/3/8/6/8/38685499/ fs-folk_medicine.pdf.

Hanitkevych, Yaroslav. 2005. The History of Ukrainian Medicine. Vesalius XI, 11: 104-106.

Jerofejev, Valerij. 2003. Unikátní metody lidových léčitelů. Eko-konzult.

Keane, Anne. 1997. Too hard to swallow? The palatability of healthy eating advice. In: Caplan, Pat (ed.): Food, Health and Identity. London and New York: Routledge: 172-192. Kindl, Josef. 2010. O nemocech, stonání a léčení na Volyni. Sdružení Čechů z Volyně a jejich př́tel 3. Klymasz, Andrea K. 1989. Ukrainian Folk Medicine in Canada. Material Culture Review/Revue de la culture matérielle, vol. 29. [2015-09-24] Dostupné z: https://journals.lib.unb.ca/index.php/ MCR/article/view/17400/22612.

Komarovová, Galina. 1997. Uralský "Černobyl" a problémy etnoekologické adaptace. Český lid 84: 29-38.

Kononenko, Natalie. 2011.

Ukrainian Folklore in Kazakhstan. Folklorica XVI: 163-183.

Kužel, Stanislav. 1997. Lidé v bývalé druhé zóně. Český lid 84: 191-200.

Metivier, Henri. 2002.- Chernobyl: Assessment of radiological and health impact: 2002 Update of Chernobyl 10 years on. Paris: OECDNEA.

Mucz, Michael. 2012. Baba's Kitchen Medicines. Folk Remedies of Ukrainian Settlers in Western Canada. The University of Alberta Press.

Ong, Chi-Keong - Bodeker, Gerard C. 2002. Use of complementary and alternative medicine services in England. American Journal of Public Health 92: 1653-1656.

Phillips, Sarah Drue. 2002. Half-Lives and Healthy Bodies: Discourses on 'contaminated' food and

healing in post-Chernobyl Ukraine.

Food \& Foodways 10: 1-27.

Phillips, Sarah Drue. 2004. Waxing Like the Moon: Women Folk Healers in Rural Western Ukraine. Folklorica IX: 13-45.

Phillips, Sarah Drue. 2013. Fukushima is not Chernobyl? Don't be so sure. Somatosphere, March 11. [2015-01-21] Dostupné z: http://somatosphere. net/2013/03/fukushima-is-notchernobyl-dont-be-so-sure.html.

Petryna, Adriana. 2002. Life Exposed: Biological Citizens after Chernobyl. Princeton: Princeton University Press.

Petryna, Adriana. 2004. The science and politics of Chernobyl-exposed populations. In: Good, Byron J. (ed.) et al. 2010: A Reader in medical anthropology. Theoretical trajectories, emergent realities. USA: Wiley-Blackwell: 199-212.

Polák, Josef. 1943. Mze (stírat mze). Naše řeč 27, 3. Ústav pro jazyk český Akademie věd ČR, v. v. i. [2015-08-13] Dostupné z: http://nase-rec.ujc. cas.cz/archiv.php?art=3751.

Rinkevicius, Leonardas. 2000. Public risk perceptions in a 'double risk' society: The case of the Ignaline Nuclear Power Plant Lithuania. Innovation: The European Journal of Social Science Research 13: 279-289.

Scott, Diana. 1996. Healing in the Shadow of Chernobyl. Albion Monitor, May 5. [2016-01-11] Dostupné z: http://www.albionmonitor.com/55-96/chernobylshadow.html.

Shokeid, Moshe. 1992. Commitment and Contextual Study. Cultural Anthropology 7, 4: 464-477.

Stickley, Andrew - Koyanagi, Ai Richardson, Erica - Roberts, Bayard Balabanova, Dina - McKee, Martin. 2013. Prevalence and factors associated with the use of alternative (folk) medicine practitioners in 8 countries of the former Soviet Union. Biomedcentral Complementary and Alternative Medicine 13: 83. [2016-01-20] Dostupné z: http://www.biomedcentral. com/1472-6882/13/83. 
Strathern, Marilyn. 2004. Partial Connection. Oxford: Altamira Press. 2. Edition.

Uherek, Zdeněk et al. 2003. Češi z Kazachstánu a jejich presídlení do České republiky. Praha: Etnologický ústav AV ČR, v. v. i.

Uherek, Zdeněk. 2009. Immigrants from the Ukraine in the Czech Republic: Foreigners in the Border Zone. In: Kürti, Laszlo - Skalník, Petr (eds.): Postsocialist Europe: Anthropological Perspective from Home. New York: Berghahn: 270-294.

Uherek, Zdeněk - Beranská, Veronika. 2015. Pavlivka Iodine Spring Water: Transnational Entrepreneurship in PostTransition Contexts. In: Červinková, Hana - Buchowski, Michał Uherek, Zdeněk (eds.): Rethinking Ethnography in Central Europe. New York: Palgrave Macmillan: 75-88.
Valášková, Nad'a - Uherek, Zdeněk Brouček, Stanislav. 1997. Aliens or One's Own People: Czech Immigrants from the Ukraine in the Czech Republic. Praha: Institute of Ethnology of the Academy of Sciences of the Czech Republic.

Wallace, Claire - Stola, Dariusz. 2001. Patterns of Migration in Central Europe. Houndmills, New York: Palgrave.

[WHO] Traditional Medicine: Definitions. World Health Organization. [2016-01-12] Dostupné z: http:// www.who.int/medicines/areas/ traditional/definitions/en/. 